Cinémas

Revue d'études cinématographiques

Journal of Film Studies

\title{
Cognitive Film Theory : An Insider's Appraisal
}

\section{Carl Plantinga}

Volume 12, numéro 2, hiver 2002

Cinéma et cognition

URI : https://id.erudit.org/iderudit/024878ar

DOI : https://doi.org/10.7202/024878ar

Aller au sommaire du numéro

\section{Éditeur(s)}

Cinémas

\section{ISSN}

1181-6945 (imprimé)

1705-6500 (numérique)

Découvrir la revue

Citer cet article

Plantinga, C. (2002). Cognitive Film Theory : An Insider’s Appraisal. Cinémas, 12(2), 15-37. https://doi.org/10.7202/024878ar

\section{Résumé de l'article}

Cet article évalue la contribution de l'approche cognitive aux études cinématographiques et indique les voies à emprunter pour que cette approche soit aussi efficace et utile que possible. L'auteur montre d'abord que les études " cognitivistes » du cinéma ne sont telles qu'au sens large du terme et qu'elles pourraient tout aussi bien être qualifiées d'« analytiques ». Il fait ensuite valoir que l'approche cognitive serait plus utile si elle était appliquée de façon plus générale, devenant alors davantage un engagement en faveur de la rationalité du discours et de la pensée humaine qu'un projet se tenant strictement dans les limites de la psychologie. Enfin, il démontre l'utilité de l'approche cognitive pour la compréhension du pouvoir psychologique du cinéma et de l'esthétique du film. 


\title{
Cognitive Film Theory: An Insider's Appraisal
}

\section{Carl Plantinga}

\begin{abstract}
RÉSUMÉ
Cet article évalue la contribution de l'approche cognitive aux études cinématographiques et indique les voies à emprunter pour que cette approche soit aussi efficace et utile que possible. L'auteur montre d'abord que les études «cognitivistes » du cinéma ne sont telles qu'au sens large du terme et qu'elles pourraient tout aussi bien être qualifiées d' "analytiques". Il fait ensuite valoir que l'approche cognitive serait plus utile si elle était appliquée de façon plus générale, devenant alors davantage un engagement en faveur de la rationalité du discours et de la pensée humaine qu'un projet se tenant strictement dans les limites de la psychologie. Enfin, il démontre l'utilité de l'approche cognitive pour la compréhension du pouvoir psychologique du cinéma et de l'esthétique du film.
\end{abstract}

\section{ABSTRACT}

This article appraises the contributions of what has been called cognitivism or the cognitive approach to film studies, and suggests the means by which the cognitive approach can become more central to film studies than it has been so far. The author first shows that much of what has been called "cognitivist" film studies is only cognitivist in a broad sense, and could just as well be called "analytic." He then argues that the cognitive approach would be most useful when it is thus broadly applied, becoming then more a commitment to the rationality of discourse and human thought than a narrow project within psychology. The article then goes on to appraise the utility of the cognitive 
approach in our understanding of the psychological power of film and film aesthetics.

Having recently returned from the third biennial symposium of the Center for Cognitive Studies of the Moving Image, ${ }^{1}$ I write this appraisal of the current state of cognitive film theory with enthusiasm. The success of this third symposium, held at the University of Pécs in Pécs, Hungary, from May 21-25, 2001 , holds promise that the cognitive approach has a future in the interdisciplinary study of film. The cognitive approach has a small but growing number of adherents, with strong international and interdisciplinary participation. The twenty-five speakers at the symposium were psychologists, philosophers, film scholars, and graduate students hailing from nine countries. (Interest in the cognitive approach seems to be stronger in Europe than in North America; most of the speakers were European.)

One of the most attractive features of the symposium is the congeniality that stems from a sense of common purpose. Adherents to the cognitive approach have significant differences; the commitment to similar principles of academic discourse, however, allows for more productive discussion and debate than is sometimes found at academic film conferences. In fact, one sign of the health of the symposium is the growing interest of scholars who do not call themselves cognitivists (or at least not primarily cognitivists) and whose scholarship centres on other approaches.

To begin I'd like to characterise the cognitive approach in two ways, historically and conceptually, and to assess the strengths and successes of the approach. Next I'll turn to problematic issues and the weaknesses of the approach. I'll end the essay with an assessment of the future of "cognitive film theory," whatever this phrase may come to mean.

\section{A Brief History of the Cognitive Approach}

The cognitive approach was introduced in the mid- to late1980 s with a series of books and essays that began to make a decisive difference in how scholars think about the study of 
film. Nineteen eighty-five marked the appearance of David Bordwell's Narration in the Fiction Film and Bordwell, Janet Staiger, and Kristin Thompson's The Classical Hollywood Cinema: Film Style and Mode of Production to 1960. These books make a powerful case for the study of film form and spectator psychology based on the kinds of mental activities described by cognitive psychology. Bordwell further clarified this methodology in his 1989 "A Case for Cognitivism" and the 1990 "A Case for Cognitivism: Further Reflections."

While Bordwell was developing a new method for film study, Noël Carroll was busy discrediting the conventional methodologies. Carroll dropped a "bombshell" on the discipline of film studies, first with a spirited attack on the psycho-semiotic film theory of Stephen Heath in the journal October, and then a few years later with his 1988 Mystifying Movies: Fads and Fallacies in Contemporary Film Theory. Mystifying Movies critiqued the thenreigning paradigm of film theory, a combination of Lacanian psychoanalysis, Althusserian Marxism, and Barthesian semiotics. After systematically arguing against the main tenets of this Theory, Carroll's conclusion was characteristically uncompromising. Such theory, he writes, has "[...] impeded research and reduced film analysis to the repetition of fashionable slogans and unexamined assumptions" (Carroll, 1988, p. 234). He argued that it must be completely discarded and we must begin anew. Carroll squarely challenged the legitimacy of film theory as it was being practised in the 1970s and 1980s, and in a way that made it difficult for film theorists to ignore.

Bordwell and Carroll continued the assault with their collection of essays, the 1996 Post-Theory: Reconstructing Film Studies. The frontispiece of the paperback edition of this book caused some resentment, as its photograph of schoolboys Laurel and Hardy, standing confused before a blackboard covered with misspelled words and bad arithmetic, could be seen as a visual metaphor for bad theory and confused theorists. Yet the polyvalence of the cover image suggests more; one could also see the Laurel and Hardy characters as Bordwell and Carroll attempting to make sense of arcane academic systems. On either interpretation, however, this book is clearly designed to mark a decisive 
intervention in the field, and not necessarily to preserve diplomatic relationships with the psycho-semioticians whom it critiques. $^{2}$

It could be argued that Bordwell and Carroll's polemics were necessary interventions in a field that had become locked into an orthodox theory that many found to be unacceptable. The outcome has not been a Kuhnian-style paradigm shift; there has been no academic revolution. Cognitive theory has had influence, but it is still practised by a minority of film scholars, if not exactly on the margins of film studies, then certainly not in the mainstream either. Yet Carroll and Bordwell's polemics cracked the film theory shell, and thus served film studies well. "Psychosemiotic" theory is on the wane, and the field has become more diverse and open to varied sorts of approaches. Many cognitivists hope that the polemical interventions are behind us, and that we can begin to concentrate on the positive contributions the cognitive approach has to offer the study of film. Indeed, Post-Theory, although it critiques the reigning paradigm, primarily consists of positive scholarship, demonstrations of the cognitive approach in relation to theoretical, xsthetic, psychological, and historical topics in film. Positive scholarship must be the focus of future efforts by cognitive theorists.

Although Bordwell and Carroll have been the most important figures in promoting the cognitive approach, the work of many other scholars has made significant contributions. The theories of Hugo Münsterberg, Sergei Eisenstein, and other early film theorists initiated the study of the psychology of film from a broadly cognitive perspective. There is a long tradition of thinking about the psychological effects and processes of film viewing from perspectives other than psychoanalysis. ${ }^{3}$

Joseph and Barbara Anderson are two of the earliest and most consistent proponents of cognitive film theory in its current manifestation. ${ }^{4}$ Joseph Anderson heads the Center for the Cognitive Study of the Moving Image, and oversees the regular symposia of the centre, while Barbara Anderson contributes in many ways, not least by offering excellent symposia papers on various topics in cognitive theory. Joseph Anderson's (1996) relatively recent book, The Reality of Illusion: An Ecological 
Approach to Cognitive Film Theory, is a valuable resource for anyone wishing an introduction to the cognitive approach, albeit from an "ecological" perspective (as I will discuss below). Other books from a broadly cognitive perspective have recently examined classical narrative technique (Thompson, 1999), narrative comprehension (Branigan, 1992), non-fiction film (Plantinga, 1999), character engagement (Smith, 1995), the avant-garde (Peterson, 1997), film and spectator psychology (Currie, 1995; Persson, 2001), and, in two collections of essays, a broad spectrum of film-related issues (Allen and Smith, 1997; Carroll, 1996).

For some time it was thought that a weakness of the cognitive approach was its inability to deal with the elicitation of emotion in film. The cognitive approach to the emotions, however, has been central in philosophy, psychology, and other major disciplines for twenty years, and recent publications have brought such methodology to bear on film (Grodal, 1997; Plantinga and Smith, 1999; Tan, 1996). Warren Buckland's The Cognitive Semiotics of Film (2000) argues for a "European" mode of cognitive film thecry differing from the theory so far described in its reliance on linguistics and semiotics. In his book Buckland details the contributions of Michel Colin, Francesco Casetti, Christian Metz, Roger Odin, Dominique Chateau, and others.

Within the discipline of film studies, the presence of cognitive theory is becoming increasingly visible. The work of cognitivists has been published in prominent anthologies, and the approach is a more consistent presence in conversations among film scholars. There is still much opposition, as Greg Currie writes, "[...] for a supposed adherence to positivism and hence for a betrayal of the new, radical insights of those approaches to film that have emerged in the wake of structuralism" (Currie, 1999a, p. 105). And indeed, this refusal to "see the light" causes some to dismiss cognitive theory as naïve or politically retrograde. In his summary and critique of cognitivism, for example, Robert Stam (2000, p. 240) writes that cognitive theory

[...] can be viewed as a nostalgic move backward to a world prior to Saussurean differentialism, prior to the Frankfurt School indictment of "instrumental reason," 
prior to Lacan's destabilized ego, prior to Marxist and Freudian critiques of "common sense," prior to Foucault's power-knowledge nexus and the mutually constitutive relation between reason and madness .

In looking over this list of theorists, however, one wonders just who is being nostalgic. Cognitive film theory draws from some of the most recent interdisciplinary methodologies. On the other hand, while Freud and Saussure are certainly useful, they are hardly the latest thing. ${ }^{5}$

Hard feelings stemming from Bordwell and Carroll's original polemical attacks continue to dog cognitivists. Indeed, it has been the response of some in the field to wholly ignore them, seemingly hoping that they will just go away. As Stam (2000, p. 235) remarks of Post-Theory, the targets of Bordwell and Carroll's provocations "[...] reacted with olympian hauteur, rarely deigning to respond". Moreover, the ad hominem attacks on Bordwell and Carroll are not difficult to hear and read at conferences and in the pages of major film journals. One can only hope that the discussion will continue to turn away from personalities to the discussion and debate of ideas.

\section{What Defines Cognitive Film Theory?}

Excellent summaries of the cognitive approach exist elsewhere (Bordwell, 1989a and 1990; Brooks, 1984; Currie, 1999a), so in this section I will be brief. At the broadest level, cognitive theorists are committed to clarity of exposition and argument and to the relevance of empirical evidence and the standards of science (where appropriate). It would be a mistake to claim that cognitive theorists oppose psychoanalysis per se, although most would agree that psychoanalysis as practised in film studies has not been fruitful. Moreover, psychoanalysis seems ill-suited to account for normative behavior such as perception, narrative comprehension, social cognition, and the experience of gardenvariety emotions such as fear and pity.

Beyond such broad generalities, we can speak only of tendencies, for the kinds of methodologies and intellectual commitments that fall under the rubric "cognitive theory" are broad indeed. In part this stems from the elusiveness of the term "cog- 
nitive theory," and hence, "cognitive film theory." To restrict cognitive film theory to theory rooted in cognitive science would clearly be far too narrow, and also plainly inaccurate. ${ }^{6}$ Traditionally, cognitive science has searched for the processes underlying intelligent problem solving, or information processing, using the computer as a metaphor for the human mind. And although cognitivists have mostly left the computer analogy behind, they have approached certain elements of narrative comprehension and perception using models of rationality and practical problem-solving. When Bordwell writes of the schemas, inferences, hypotheses, and assumptions used in film viewing, he assumes a spectator engaging in goal-directed, primarily non-conscious procedures to make sense of film narratives.

Yet in the work of other cognitivists, one sees strains that emerge from outside of cognitive science proper. Joseph Anderson's The Reality of Illusion, for example, is typical of much cognitive theory in its hybrid methodology, melting a combination of cognitive theory strictly defined, an ecological approach derived from J. J. Gibson, and evolutionary psychology. Furthermore, although cognitivists are obviously interested in cognition in relation to the film spectator, some have begun to take a strong interest in neuroscience and its relation to spectator psychology. When reading Torben Grodal's Moving Pictures (1997), for example, one finds many references to the physical processes of the embodied brain in relation to cognitive processes. The cognitive philosophers, on the other hand, are less interested in neuropsychology than in rational thought processes and logical argument. Noël Carroll's The Philosophy of Horror (1990), for example, theorises the phenomenon of horror in purely cognitive and rationalistic terms.

I could go on to enumerate similar examples. The point is that "cognitive film theory" does not necessarily imply a commitment to cognitive science, strictly defined, and certainly not to cognitive science exclusively. One might say that cognitive film theorists tend to be committed to the study of human psychology using the methods of contemporary psychology and analytic philosophy. This can be an amalgam of cognitive, evo- 
lutionary, empirical, and/or ecological psychology, with perhaps a bit of neuroscience and dynamical systems theory thrown in the mix.

Cognitive film theorists not only differ in methodology, but also in fundamental beliefs about human psychology, or, as in the following example, psychology in relation to ontology. To take one case, David Bordwell's brand of theory is constructivist in its assumption that perceptual and cognitive activity goes beyond the information given. As Bordwell writes (1989a, p. 18), perception " $[\ldots]$ is not a passive recording of sensory stimulation; the sensory input is filtered, transformed, filled in, and compared with other inputs to build, inferentially, a consistent, stable world". For Bordwell, the spectator constructs the fabula, or story, of the fiction film in the process of viewing. The degree to which that constructed fabula is consistent from viewer to viewer depends on what kind of processes are used to construct it. Bordwell (1989a, p. 22) distinguishes between neurological processes, universal cognitive processes, and culturally variable cognitive processes.

Gregory Currie, from a realist perspective, questions this constructivism, asking what advantage it provides to say that the meaning of a work is constructed rather than discovered by the viewer. Currie takes Bordwell's motivation to be to posit an active rather than passive spectator, in part to counter psychoanalytic assumptions about the passive spectator of the classical text. Currie claims that this is a poor motivation. It does not take constructivism to find an active spectator; isn't the discovery of the text's meaning, he asks, also an active response? Currie notes that Bordwell cannot be a realist with regard to narrative meaning, since Bordwell must posit that such meaning is constructed and not there, in the film, to be discovered. Bordwell is a constructivist in this regard, but a realist in another sense, "[...] on the important issue of the existence and significance of connections between the narrative and the real world" (Currie, 1999a, p. 113).$^{8}$ Most cognitivists, including Bordwell and Currie, tend to favour naturalistic explanations of filmic phenomena that assume that we make sense of films in many of the same ways we make sense of the real world. 
All of this is to reiterate a claim often made before; cognitivists have developed an approach rather than a well-defined theory. What defines the approach is a commitment to clarity of discourse, vigorous debate, and a loose family of assumptions about workable means to study film and film spectatorship. Chief among these assumptions is Bordwell and Carroll's call for "piecemeal" theory, an emphasis on middle-level research that chooses small, manageable questions for investigation. Bordwell bemoans the tendency in film studies to "[...] exude a sweeping confidence that we are on the verge of the next Big Theory of Everything," and he denies that cognitivism is such a theory. He ends his essay about cognitivism with a proviso: "All this could turn out to be wrongheaded and useless" (Bordwell, 1989a, p. 33). Cognitivism may eventually be superceded by or melded with another, more sophisticated psychological theory. Most theories are superceded. As Bordwell (1989a, p. 33) writes, we can only hope that it will have been "[...] a little bit right and somewhat useful here and there".

The cognitive approach is committed to middle-level research about film and film spectatorship, with an appreciation for "bottom-up theory" that is sometimes denigrated in other areas of film theory. Of course, this is not to deny that some cognitivists bear a fervor for large scale commitments or make broad foundational assumptions. It is more to say that some middlelevel research can be conducted independent of those assumptions, and can be of use to scholars from diverse perspectives. ${ }^{?}$

\section{What Has Cognitive Film Theory Accomplished?}

Cognitive film theory, broadly considered, has made significant contributions to the study of film. Here I will mention only those contributions with which I am most familiar, and apologize in advance to those to whom I give short shrift. Cognitive theory today is primarily interested in how spectators make sense of and respond to films, together with the textual structures and techniques that give rise to spectatorial activity and response. The most sustained contributions thus far have been made by David Bordwell and Noël Carroll. David Bordwell's work includes theoretical treatises on filmic narration 
(Bordwell, 1985) and film interpretation (Bordwell, 1989b), in addition to several excellent director studies. From the standpoint of cognitive theory, Bordwell has established a constructivist approach (as detailed above) and has developed an attractive and compelling theory of filmic narration. Bordwell's theory of narration is useful, for example, in distinguishing between classical Hollywood cinema and art cinema, and in describing the mental activities of the film spectator. ${ }^{10}$ Bordwell's approach is to pay close attention to the formal workings of films in relation to the theory of narration he has developed. His work is unsurpassed in the application of a particular methodology to film style (Bordwell, 1998b), or to the study of various film directors and films, as in his studies of Eisenstein (Bordwell, 1993), Ozu (Bordwell, 1988), and Hong Kong cinema (Bordwell, 2000).

Noël Carroll's work also is wide-ranging, having touched on almost every major topic in the theory of film. In my opinion, some of his best work deals with the psychology of film spectatorship, and can be found in several essays in Theorizing the Moving Image (1996). Like Bordwell, Carroll has been interested in filmic perception and narrative comprehension, but Carroll's interest extends to the spectator's motivations and emotions, and to what makes the movies such a widespread and intense experience for people worldwide (Carroll, 1996, p. 7893). Carroll has written on the relationship between genre and emotion (in Plantinga and Smith, 1999, p. 21-47), on horror (Carroll, 1990), suspense (Carroll, 1996, p. 94-117), and the relationship between point-of-view editing and emotion (Carroll, 1996, p. 125-138).

The study of the means by which films elicit emotion has become a major area of interest in cognitive film theory of late. Books by Grodal, Tan, Plantinga and Smith, Currie, and Carroll have all shown that the cognitive approach has much to tell about how films elicit emotion. Their basic assumption is that emotions have reasons. In other words, our emotional response to texts (and other phenomena) is dependent in part on how we evaluate and assimilate textual information. Thus the rhetoric of a text is not simply about ideas, but also about emotional 
responses. Cognitive film theory argues that in responding to films, thinking; and feeling are intimately related.

Character identification, or what Murray Smith prefers to call character "engagement," is one of the dominant means by which we become involved in a film emotionally. Smith argues that one primary mode of engagement, what he calls the structure of sympathy, is a process that has three components: 1) recognition, by which the spectator constructs the character; 2) alignment, by which spectators are placed in relation to characters both visually and epistemically; and 3) allegiance, by which spectators morally evaluate characters. Smith's theory is elegant, intuitively plausible, and useful in gauging the rhetori$\mathrm{cal}$ and resthetic functions of individual films, as his film analyses show. These are ideas, I believe, that will have a long life in the study of film in relation to spectator response. (At the 2001 Symposium mentioned above, Jonathan Frome delivered an excellent papes, entitled "Revisiting Identification," in which he extended and critiqued Smith's theory of character engagement.)

Character engagement is one of the ways that the text primes the emotional response of the viewer. If an emotion results in part from an evaluation of a situation, our assessment of the meaning of a situation for a favoured character will become a major part of that evaluation. Emotional response also depends on the nature of the situation presented, however, and on the way the situation unfolds. In this way, particular sorts of narrative scenarios are associated with specific emotions-the family melodrama with sentiment, action/adventure with suspense and excitement, the romantic comedy with amusement and sentiment, etc. The relationship between narrative and emotion has been the subject of a recent flurry of publications, but it is nonetheless at a preliminary stage. One daunting question is the degree to which film-elicited emotions are similar and dissimilar to garden-variety emotions we experience in our actual, extrafilmic lives. We also need a better understanding of the specificity of the film medium in the evocation of emotion. Some studies have attempted to come to grips with certain elements of this specificity, considering the use of point of view editing (Carroll, 1996), the represented human face (Plantinga, 1999), "align- 
ment" (M. Smith, 1995), and film music (J. Smith, 1999) in relation to emotion. Much remains to be done, obviously.

In the study of the non-fiction film, cognitive theorists have made a substantial contribution as well. Both traditional and post-structuralist critics tended to take the non-fiction film as a kind of imitation or reconstruction of reality. Such a view creates problems for the very notion of documentary, because one can easily find the techniques by which documentaries manipulate their materials (and thus "the real"). This leaves open the charge that the fiction/non-fiction distinction is illicit, that documentaries make use of fictional techniques, and even that documentaries are duplicitous in their pretence to deliver a pristine reality when in fact they are manipulated and rhetorically purposeful. This way of thinking defines the documentary in such a way that no film could possibly meet its requirements, then castigates documentaries for pretending to do so!

These confusions stem from the faulty notion that a non-fiction film pretends to be or is taken as a perfect rendition or copy of some pro-filmic event or real-world subject. Instead, I have argued that it makes more sense to think of a non-fiction film in light of action theory, a broad derivation of speech act theory (Plantinga, 1987). Non-fiction films are those films through which the filmmaker(s) assert, and about which the spectator assumes, that "[...] given objects, entities, states of affairs, events, or situations actually occur(red) or exist(ed) in the actual world as portrayed" (Plantinga, 1997, p. 18). This suggestion has been subsequently revised, refined, and critiqued (Carroll, 1997; Currie, 1999b; Ponech, 1999).

The distinction between fiction and non-fiction, then, stems not from any necessary textual differences between fictional and non-fictional films, but from the use to which the text is put within a world of discursive action. Non-fiction films, like governments, money, and birth certificates, function the way they do because we assign them a certain status, and because that status is taken up by a broader community and acted upon. To put it baldly and much too simply, prototypical non-fictions are used to provide direct information and/or arguments, and prototypical fictions to present imaginary worlds and stories. The tech- 
niques used for these separate functions will often be similar for fiction and non-fiction films, and it is not the case, for example, that continuity editing or the use of non-diegetic music is a fictional rather than a non-fictional technique. They are film techniques that can be used in both fiction and non-fiction films.

The spectator, then, may well use similar, though not identical, strategies of perception, comprehension, and interpretation when viewing fiction and non-fiction films. We can nonetheless distinguish the prototypes based on instrumental factors such as the intended and actual functions of the films within the world of human discourse. This is the level at which the distinction between fiction and non-fiction runs the deepest.

\section{What Must Cognitive Film Theory Do Better?}

Since the cognitive approach to film theory is a recent phenomenon, it is unsurprising that much more needs to be done, both in extending the kinds of work already accomplished and in branching into new directions. There is certainly no area of film scholarship that is closed, no question that has been fully answered and explored. But is cognitive theory on the right track? The film studies establishment has critiqued cognitivism for its alleged commitment to science and objectivity and its seeming lack of concern for the cultural issues that currently occupy film studies. With regard to the use of scientific method, evidence, and/or logical reasoning, cognitivists must plead guilty as charged. Most of us find the methods of science, logical reasoning, clarity of discourse, and/or the appeal to evidence to be central to what we do. But this by no means implies positivism, empiricism, reductionism, or, to put it baldly, epistemic arrogance. All methods of human inquiry are fallible. We must simply work with the best methods available to us, always ready to revise our conclusions in light of new evidence. Moreover, there may be some questions for which humanistic inquiry of another kind is still the best approach. For many questions, however, broadly "scientific" or analytic methodologies are the best means of investigation.

Robert Stam (2000, p. 240-241) writes of the cognitive theorist's "[...] touching faith in reason (after Auschwitz) and science (after Hiroshima)." 
Cognitivism, he writes, keeps its faith with science, even though "science" had not so recently "proved" black, Jewish, and Native American inferiority. The question, of course, is to what end is science being used, and who gets to decide.

Stam's points here are confused. Surely reason and science enabled the scale of the killing at Auschwitz and Hiroshima. They aren't the root cause of such killing, however. Is the fact that science has been used to such ends reason enough to abandon science? Surely reason and science have been used to promote the inferiority of races and ethnicities. But reason and science aren't the root causes of such racism and oppression. And science never proved Jewish or black inferiority, although some scientists may have attempted to do so.

If Stam's claim is that reason and science are tools that can be used for good or for ill, then he is surely right. I know of no cognitive theorist who blindly embraces all scientific projects or findings, or who denies that science can be used in atrocious ways. Cognitive theorists believe that the tools of science are useful for the study of certain middle-range problems having to do with film and the psychology of spectatorship. Instead of castigating cognitive theorists for a broad "faith in science and reason," a more useful critique of cognitivism would either show how appeals to evidence and argument fail generally, or demonstrate that cognitivists use these tools in irresponsible or politically retrograde ways. I have not seen such a critique.

This leads to the second issue, the claim that cognitive film theory is uninterested in "alterity" and the cultural and political concerns thought normative in much of film studies-gender and gender roles, race, ethnicity, sexual orientation, etc. While cognitive theorists have dealt with issues such as gender (e.g., Carroll, 1996, p. 260-274; Freeland, 1996; Leibowitz, 1996), the heart of cognitive theory lies outside of the cultural concerns of mainstream film studies. This in itself might be of little concern, since film theory has shown itself to be fickle, and the idea that some scholars might take an interest in questions other than those $d u$ jour is hardly alarming. 
Yet at the same time, many cognitive theorists are sympathetic to the general political bent of the film studies discipline, that is, to gender and racial equality, to multiculturalism, and to the promotion of equality and tolerance for ethnic and sexual minorities. Some film scholars, unfortunately, seem to think that cognitivists whose work doesn't directly touch on these issues are somehow ideologically suspect. I don't know what can be done about such blinkered thinking (let alone the conformist assumption that all in film studies must share a particular political project).

On the other hand, however, since many cognitivists are committed to the field's political concerns, perhaps it is time to produce scholarship that demonstrates the usefulness of cognitive film theory in answering the questions pertinent to the politics of location. One of the chief roadblocks here is that cultural theorists are currently enamored of "difference" while the cognitive theorists appeal to universalistic or naturalistic explanations for spectator behaviour. For many film theorists, "difference" is a key concept--in fact, a foundational idea in the determination of how spectators respond to films. Feminist film theory, one of the major strains of film theory today, depends wholly on the idea that spectatorship is gendered, and that films elicit gendered responses. Cultural studies approaches emphasise the idiosyncrasies of particular historical communities in responses to film, and downplay any sense of a spectator with universal characteristics. For such theorists, the cognitivist appeal to human nature runs against the grain. Again to quote Stam (2000, p. 241), cognitive theory

\begin{abstract}
[...] allows little room for the politics of location, or for the socially shaped investments, ideologies, narcissisms, and desires of the spectator, all of which seem too irrational and messy for the theory to deal with.
\end{abstract}

In defence of cognitivism, one must first note that neither appeals to human difference nor to human similarities have an inherent political perspective. Film theorists typically assume that claims for human nature are politically dangerous, since they establish normative behavior against which alternatives 
may be found to be perverse or inferior. Yet appeals to differences between races or genders have long been a favourite tool of the oppressor, and claims for the essential equality of all humans have been instrumental in campaigns for emancipation. ${ }^{11}$ In fact, cultural theorists cannot escape various universalist assumptions, such as assumptions about the equal worth of all races, genders, and ethnicities, the immorality of oppression, etc. The cognitivist search for far-reaching naturalistic explanations of human behaviour, then, is not necessarily a political handicap, any more than an emphasis on difference necessarily favours tolerance.

Second, it is obvious that humans share basic characteristics that have far-reaching effects on our behaviour. Some of these more or less universal characteristics directly relate to the film viewing experience. This assumption constitutes a fundamental strength of cognitive film theory, its examination of what Bordwell calls "contingent universals,"(Bordwell and Carroll, 1996, p. 91-92) ${ }^{12}$ similarities between spectators, ordinary states of mind (rather than the pathological states of interest to the psychoanalyst), and the everyday abilities and characteristics that allow us to make sense of and respond to movies and the world.

Perhaps some would say that such claims are true but fundamentally uninteresting or unproductive. Stam (quoted in Quart, 2000, p. 41) has remarked, for example, "[Film] Cognitivists say that all viewers have the same perceptual apparatus. That's like saying we all defecate. So what?" Of course, using similar rhetoric, one could also easily caricature and belittle the claims for difference and heterogeneity. To claim that the only elements worth investigating are those that differentiate us seems rather narrow, as though everybody already knows our commonalities. If our commonalities are so well known and understood, then of course there is no further need for research into human emotion, perception, cognition, medical science, etc. This is implausible. To understand spectatorship, one must understand what spectators share in common, and those commonalities are often not matters of common knowledge. The proper method to explore spectatorship, it seems to me, is to investigate the "con- 
tingent universals" of spectatorship, the similarities across various social groups (gender, culture, nation, etc.), and the means by which "the politics of location" and numerous other factors inflect these characteristics.

Cognitive theory should provide useful tools for the study of the politics of location, or if you will, alterity. Given that we begin with contingent universals, the addition of the influences of location-historical contingencies, ethnicity, race, gender, sexual orientation, etc.-typically result in variations in social cognition. As Bordwell (1989a) reports, the cognitivist framework has influenced a broad array of disciplines, including sociology, anthropology, and history. Working within such a framework leads the researcher to show how social action is mediated by mental representations, and how such mental representations-schemata, scripts, mental models-organise cultural life. In fact, sophisticated new approaches in sociology and social cognition are available to be exploited by those analyzing film. ${ }^{13}$

Understanding how a movie plays differently in the suburbs versus the inner city, or in Dallas versus Paris or Sao Paulo, for example, would involve a cultural analysis of the mental models under use by the audience. Is it true that Germans and Americans tend to respond differently to sentimental films, and if so, what is the difference? Does the interactive nature of the film viewing experience in some cultures influence emotional response? How does political opposition to a film's ideological "project" influence emotional response? Researchers have shown that certain genres appeal predominantly to men and others to women. What social schemas or scripts are at work to determine such likes and dislikes? Why are certain films popular in some countries and not in others? How is cross-cultural emotional response to films influenced by varied emotion scenarios or scripts in the culture at large? And is the globalisation of the media working to homogenise the emotional lives of diverse populations? The tools of the cognitivist could be useful in helping to answer all of these questions. 


\section{Prospects for the Future}

As I wrote at this essay's start, those who attended the third symposium of the Center for Cognitive Studies of the Moving Image left excited about the future of the organisation and the cognitive approach it represents. As the semi-official institution behind cognitive film theory, the centre, headed by Joseph Anderson at Georgia State University in Atlanta, has an important role to play in disseminating information, maintaining esprit de corps, and organising regular conferences. The organisation's board of directors, at their post-symposium meeting, sensed a good deal of enthusiasm and momentum among those who attended. They concluded that it was time to take steps to expand the activities of the centre. These steps will include a move towards an annual conference, the establishment of a refereed on-line journal to be called The Journal of the Moving Image, and an expansion of the centre's website to feature links to salient essays and e-books (see endnote \#1 for the website address).

Cognitive film theorists have no ambition to make cognitive theory the dominant research mode in the field. Were this within the realm of possibility, it could never be a goal. Most cognitivists now are more committed to a broad research program than to any particular theory, narrowly considered. Ideally, the opportunities for vigorous academic debate and friendly disputation will remain both within the pages of the new journal and at future symposia. Not all film-related questions can be answered using the cognitive approach. Nonetheless, I remain firmly convinced that the approach has been effective in its investigation of certain problems. Its popularity within the discipline of film studies is limited, but it elicits interdisciplinary interest. And the quality and innovation of the work that cognitivists continue to produce promises good things for the future. $^{14}$ 


\section{NOTES}

1. Those wishing further information on the CCSMI should visit its website at http://www.gsu.edu/ - wwwcsm/. Both Laszlo Tarnay at the University of Pécs, and Joseph Anderson, director of CCSMI, were instrumental in planning and coordinating this symposium.

2. Two books that generally summarize and stand for what Post-Theory is aimed against are Reinventing Film Studies (Gledhill and Williams, 2000) and New Vocabularies in Film Semiotics: Structuralism, Post-Structuralism, and Beyond (Stam, Burgoyne and Flitterman-Lewis, 1992).

3. See Allan Langdale (2002). See Langdale's introduction to the volume for the implications of Münsterberg's work for cognitive studies. Also see The Film Form (Eisenstein, 1977) and The Film Sense (Eisenstein, 1974).

4. See "The Myth of Persistence of Vision" (Anderson and Fisher, 1978). Also see "The Myth of Persistence of Vision Revisited" (Anderson and Anderson, 1993).

5. For a review of Stam's book and a comment on his treatment of Murray Smith's ideas and cognitive film theory, see "Review Article: Theory Misadventure and Critical Choices" (Williams, 2001).

6. A fine overview of cognitive science can be found in The MIT Encyclopedia of the Cognitive Sciences (Wilson and Keil, 1999). For an overview of cognitive science and the arts, see Cynthia Freeland's two-part essay "Teaching Cognitive Science and the Arts" (Freeland 200la and 2001b), published by the American Society for Aesthetics, and available online at <aesthetics-online.org>.

7. The mind-as-computer metaphor does not sit comfortably with many contemporary cognitive theorists, and especially with a growing number of those who foreground the importance of the body in everyday cognition. One strain of cognitive theory that emphasises the body stems from George Lakoff and Mark Johnson. See their Philosopby and the Flesh: The Embodied Mind and Its Challenge to Western Thought (Lakoff and Johnson, 1999).

8. Bordwell's constructivist approach to cognitive film theory has been critiqued and measured against other types of constructivism by Berys Gaut (1995).

9. Besides an emphasis on "middle-level" theory, cognitive theorists have also called for rigorous intellectual debate. Whether this might constitute a genuine pluralism has been an issue of some contention. For a bracing debate (that was cut short because Cinema Journal refused to print Bordwell's final rejoinder) see "Pluralism versus the Correct Position" (Lehman, 1997); "Pluralism, 'Truth, and Scholarly Inquiry in Film Studies" (Bordwell, 1998); "Reply to David Bordwell" (Lehman, 1998); "A Response to Peter Lehman's Essay 'Pluralism versus the Correct Position"” (Minnis, 1998); "Reply to Stuart Minnis" (Lehman, 1998).

10. Bordwell's work on art cinema in Narration in the Fiction Film could profitably be compared with his earlier "The Art Cinema as Mode of Film Practice" (Bordwell, 1979); with Torben Grodal's intriguing cognitive account in "Art Film, the Transient Body, and the Perrnanent Soul" (Grodal, 2000); and with standard non-cognitive approaches such as that found in Geoffrey Nowell-Smith's (1996) "Art Cinema."

11. Although this is perhaps too obvious to be stated, the institution of slavery in the United States was grounded in the differentiation between Whites and Blacks, and of course, patriarchal gender roles depend fundamentally on presumed differences between females and males.

12. For general discussions of the issue of human universals, see Human Universals (Brown, 1991); also see "Tradition and Modernity Revisited" (Horton, 1982).

13. The following are some of the books bearing on social issues from a cognitive standpoint: Social Cognition: Making Sense of People (Kunda, 1999); Social Cognition 
(Fiske and Taylor, 1991); Cultural Transactions: Nature, Self, Society (Hernadi, 1995); Moral Imagination: Implications of Cognitive Science for Ethics (Johnson, 1993).

14. I would like to thank the anonymous reviewer for CiNéMAS for helpful suggestions regarding this essay.

\section{BIBLIOGRAPHICAL REFERENCES}

Allen and Smith, 1997: Richard Allen and Murray Smith (eds.), Film Theory and Philosophy, Oxford, Clarendon Press, 1997.

Anderson, 1996: Joseph Anderson, The Reality of Illusion: An Ecological Approach to Cognitive Film Theory, Carbondale, Southern Illinois University Press, 1996.

Anderson and Fisher, 1978: Joseph Anderson and Barbara Fisher, "The Myth of Persistence of Vision," The Journal of the University Film and Video Association, vol. 30, no. 4, 1978, p. 3-8.

Anderson and Anderson, 1993: Joseph Anderson and Barbara Anderson, "The Myth of Persistence of Vision Revisited," Journal of Film and Video, vol. 45, no. 1, 1993, p. 3-12.

Bordwell, 1979: David Bordwell, "The Art Cinema As a Mode of Film Practice," Film Criticism, vol. 4, no. 1, 1979, p. 56-64.

Bordwell, 1985: David Bordwell, Narration in the Fiction Film, Madison, University of Wisconsin Press, 1985.

Bordwell, 1988: David Bordwell, Ozu and the Poetics of Cinema, Princeton, Princeton University Press, 1988.

Bordwell, 1989a: David Bordwell, "A Case for Cognitivism," Iris, no. 9, 1989, p. 11 40.

Bordwell, 1989b: David Bordwell, Making Meaning: Inference and Rhetoric in the Interpretation of Cinema, Cambridge, Harvard University Press, 1989.

Bordwell, 1990: David Bordwell, "A Case for Cognitivism: Further Reflections," Iris, no. 11, 1990, p. 107-112.

Bordwell, 1993: David Bordwell, The Cinema of Eisenstein, Cambridge, Harvard University Press, 1993.

Bordwell, 1998a: David Bordwell, "Pluralism, Truth, and Scholarly Inquiry in Film Studies," Cinema Journal, vol. 37, no. 2, 1998, p. 84-90.

Bordwell, 1998b: David Bordwell, On the History of Film Style, Cambridge, Harvard University Press, 1998.

Bordwell, 2000: David Bordwell, Planet Hong Kong: Popular Cinema and the Art of Entertainment, Cambridge, Harvard University Press, 2000.

Bordwell and Carroll, 1996: David Bordwell and Noël Carroll (eds.), Post-Theory: Reconstructing Film Studies, Madison, University of Wisconsin Press, 1996.

Bordwell, Staiger and Thompson, 1985: David Bordwell, Janet Staiger and Kristin Thompson, The Classical Hollywood Cinema: Film Style and Mode of Production to 1960, New York, Columbia University Press, 1985.

Branigan, Edward, 1992: Narrative Comprehension and Film, London and New York, Routledge, 1992.

Brooks, 1984: Virginia Brooks, "Film, Perception and Cognitive Psychology," Millenium Film Journal, no. 14, 1984, p. 105-126.

Brown, 1991: Donald E. Brown, Human Universals, Philadelphia, Temple University Press, 1991. 
Buckland, 2000: Warren Buckland, The Cognitive Semiotics of Film, Cambridge, Cambridge University Press, 2000.

Carroll, 1983: Noël Carroll, "Address to the Heathen," October, no. 23, 1983, p. 89-163.

Carroll, 1984: Noël Carroll, "A Reply to Heath," October, no. 27, 1984, p. 81-102.

Carroll, 1988: Noël Carroll, Mystifying Movies: Fads and Fallacies in Contemporary Film Theory, New York, Columbia University Press, 1988.

Carroll, 1990: Noël Carroll, The Philosophy of Horror, New York and London, Routledge, 1990.

Carroll, 1996: Noël Carroll, Theorizing the Moving Image, Cambridge, Cambridge University Press, 1996.

Carroll, 1997: Noël Carroll, "Fiction, Non-fiction, and the Film of Presumptive Assertion: A Conceptual Analysis," in Richard Allen and Murray Smith (eds.), Film Theory and Philosophy, Oxford, Clarendon Press, 1997, p. 173-202.

Currie, 1995: Gregory Currie, Image and Mind: Film, Philosophy, and Cognitive Science, Cambridge, Cambridge University Press, 1995.

Currie, 1999a: Gregory Currie, "Cognitivism,", in Toby Miller and Robert Stam (eds.), A Companion to Film Theory, London, Blackwell, 1999, p. 106-112.

Currie, 1999b: Gregory Currie, "Visible Traces: Documentary and the Content of Photographs," Journal of Aesthetics and Art Criticism, no. 57, 1999, p. 285-297.

Eisenstein, 1957: Sergueï Eisenstein, The Film Form, New York, Meridian, [1949] 1957.

Eisenstein, 1975: Sergueï Eisenstein, The Film Sense, New York, Harcourt Brace Jovanovich, [1942] 1975.

Fiske and Taylor, 1991: Susan T. Fiske and Shelley E. Taylor, Social Cognition, New York, McGraw-Hill, 1991.

Freeland, 1996: Cynthia Freeland, "Feminist Frameworks for Horror Films," in David Bordwell and Noël Carroll (eds.), Post-Theory: Reconstructing Film Studies, Madison, University of Wisconsin Press, 1996, p. 195-218.

Freeland , 2001a: Cynthia Freeland, "Teaching Cognitive Science and the Arts. Part 1: Visual Art," ASA. Newsletter, vol. 21, no. 1, 2001, p. 1-3.

Freeland, 2001b: Cynthia Freeland, "Teaching Cognitive Science and the Arts. Part 2: Film Theory," ASA Newsletter, vol. 21, no. 2, 2001, p. 1-3.

Frome, 2001: Jonathan Frome, "Identification Revisited," paper given at the 3rd Biennial Symposium of the Center for the Cognitive Study of the Moving Image, Pécs, Hungary, 2001.

Gaut, 1995: Berys Gaut, "Making Sense of Films: Neoformalism and its Limits," Forum for Modern Language Studies, vol. 31, no. 1, p. 8-23.

Gledhill and Williams, 2000: Christine Gledhill and Linda Williams (eds.), Reinventing Film Studies, London, Arnold, 2000.

Grodal, 1997: Torben Grodal, Moving Pictures: A New Theory of Film Genres, Feelings, and Cognition, Oxford, Clarendon Press, 1997.

Grodal, 2000: Torben Grodal, "Art Cinema, the Transient Body, and the Permanent Soul," Aura, vol. 6, no. 3, p. 33-53.

Heath, 1983: Stephen Heath, "Le Père Noël," October, no. 26, 1983, p. 63-115.

Hernadi, 1995: Paul Hernadi, Cultural Transactions: Nature, Self, Society, Ithaca, Cornell University Press, 1995.

Horton, 1982: Robin Horton, "Tradition and Modernity Revisited," in Martin Hollis and Stephen Lukes (eds.), Rationality and Relativism, Cambridge, MIT Press, 1982, p. 201-260. 
Johnson, 1993: Mark Johnson, Moral Imagination: Implications of Cognitive Science for Ethics, Chicago, University of Chicago Press, 1993.

Kunda, 1999: Ziva Kunda, Social Cognition: Making Sense of People, Cambridge, MIT Press, 1999.

Lakoff and Johnson, 1999: George Lakoff and Mark Johnson, Philosophy and the Flesh: The Embodied Mind and Its Challenge to Western Thought, New York, Basic Books, 1999.

Langdale, 2002: Allan Langdale (ed.), Hugo Mürsterberg on Film: The Photoplay-A Psychological Study and Other Writings, New York, Routledge, 2002.

Lehman, 1997: Peter Lehman, "Pluralism versus the Correct Position," Cinema Journal, vol. 36, no. 2, 1997, p. 114-119.

Lehman, 1998a: Peter Lehman, "Reply to David Bordwell," Cinema Journal, vol. 37, no. 2,1998 , p. $90-92$.

Lehman, 1998b: Peter Lehman, " Reply to Stuart Minnis," Cinema Journal, vol. 37, no. 2,1998 , p. $95-97$.

Liebowitz, 1996: Flo Liebowitz, “Apt Feelings, or Why 'Women's Films' Aren't Trivial," in David Bordwell and Noël Carroll (eds.), Post-Theory: Reconstructing Film Studies, Madison, University of Wisconsin Press, 1996, p. 219-229.

Minnis, 1998: Stuart Minnis, "A Response to Peter Lehman's Essay 'Pluralism versus the Correct Position," Cinema Journal, vol. 37, no. 2, 1998, p. 92-95.

Nowell-Smith, 1996: Geoffrey Nowell-Smith, "Art Cinema," in Geoffrey NowellSmith (ed.), The Oxford History of World Cinema, Oxford University Press, 1996, p. 567-575.

Persson, 2001: Per Persson, Understanding Cinema: Constructivism and Spectator Psychology, Cambridge, Cambridge University Press, 2001.

Peterson, 1994: James Peterson, Dreams of Chaos, Visions of Order: Understanding the American Avant-Garde Cinema, Detroit, Wayne State University Press, 1994.

Plantinga, 1987: Carl Plantinga, "Defining Documentary: Fiction, Nonfiction, and Projected Worlds," Persistence of Vision, no. 5, 1987, p. 44-54.

Plantinga, 1997: Carl Plantinga, James Peterson, Rhetoric and Representation in Nonfiction Film, Cambridge, Cambridge University Press, 1997.

Plantinga, 1999: Carl Plantinga, "The Scene of Empathy and the Human Face on Film," in Carl Plantinga and Greg M. Smith (eds.), Passionate Views: Film, Cognition and Emotion, Baltimore, John Hopkins University Press, 1999, p. 239-256.

Plantinga and Smith, 1999: Carl Plantinga and Greg M. Smith (eds.), Passionate Views: Film, Cognition, and Emotion, Baltimore, John Hopkins University Press, 1999.

Ponech, 1999: Trevor Ponech, What is Non-Fiction Cinema?, Boulder, Westview Press, 1999.

Prince, 1999: Stephen Prince, "The Discourse of Pictures: Iconicity and Film Studies," in Leo Braudy and Marshall Cohen (eds.), Film Theory and Criticism: Introductory Readings, Oxford, Oxford University Press, 1999, p. 99-117.

Quart, 2000: Alissa Quart, "The Insider: David Bordwell Blows the Whistle on Film Studies," Lingua Franca, vol. 10, no. 2, 2000, p. 34-43.

Smith, 1995: Murray Smith, Engaging Characters: Fiction, Emotion, and the Cinema, Oxford, Clarendon Press, 1995.

Smith, 1999: Jeff Smith, "Movie Music as Moving Music: Emotion, Cognition, and the Film Score," Passionate Views: Film, Cognition and Emotion, Baltimore, John Hopkins University Press, 1999, p. 146-167. 
Stam, 2000: Robert Stam, Film Theory: An Introduction, London, Blackwell Publishing, 2000.

Stam, Burgoyne and Flitterman-Lewis, 1992: Robert Stam, Robert Burgoyne and Sandy Flitterman-Lewis, New Vocabularies in Film Semiotics: Structuralism, PostStructuralism, and Beyond, New York, Routledge, 1992.

Tan, 1996: Ed S. Tan, Emotion and the Structure of Narrative Film: Film as an Emotion Machine, Mahwah, Lawrence Erlbaum, 1996.

Thompson, 1999: Kristin Thompson, Storytelling in the New Hollywood: Understanding Classical Narrative Technique, Cambridge, Harvard University Press, 1999.

Williams, 2001: Christopher Williams, "Review Article: Theory Misadventure and Critical Choices," Screen, no. 42, 2001, p. 230-238.

Wilson and Keil, 1999: Robert A. Wilson and Frank C. Keil (eds.), The MIT Encyclopedia of the Cognitive Sciences, Cambridge, MIT Press, 1999. 